\title{
The Role of Corticosterone in the Metabolic Recovery after Intrasplenic Adrenal Autotransplantation in Rats
}

\author{
GONZALO ALLENDE, ROBERTO CHAVIRA* AND ANDRES QUINTANAR-STEPHANO \\ Department of Physiology and Pharmacology, Basic Sciences Center, Autonomous University of Aguascalientes, Av. Universidad \\ 940, Aguascalientes, Ags, 20100 Mexico \\ *Department of Reproduction Biology, National Institute of Medical Sciences and Nutrition, Vasco de Quiroga 15, Del. Tlalpan, \\ México, DF, 14000 Mexico
}

\begin{abstract}
Transplantation of adrenal cortical tissue may represent an alternative treatment to reestablish glucocorticoid secretion in adrenal insufficiency. In the present work, performed in adrenalectomized rats and adrenalectomized rats with a complete autotransplanted adrenal into the spleen, several hormones and biochemical parameters were measured and compared to control animals, in order to examine hormone interactions. Rats were sacrificed three weeks after surgery, and plasma and tissue samples were obtained for hormone and biochemical measurements. In adrenalectomized animals, plasma corticosterone, aldosterone and insulin levels were profoundly decreased, whereas in autotransplanted rats plasma corticosterone levels showed a partial recovery, aldosterone plasma concentrations remained low, and plasma insulin levels increased to values close to those of the controls. Both groups showed a marked elevation of plasma ACTH levels, as well as significantly increased plasma glucagon concentrations. In autotransplanted animals, most of the biochemical parameters, which were altered in adrenalectomized rats, returned to normal levels. These results suggest that increased glucagon levels in adrenalectomized and autotransplanted animals, may contribute to the marked increase of plasma ACTH, and could also be important in the recovery of plasma glucose and hepatic glycogen observed in autografted rats. Since high glucagon concentrations alone were unable to normalize carbohydrate levels in adrenalectomized animals, it appears that glucagon can act only in the presence of corticosterone.
\end{abstract}

Key words: Autotransplantation, Adrenal, Spleen, Corticosterone, Glucagon

(Endocrine Journal 51: 325-332, 2004)

\begin{abstract}
ADRENAL transplantation may be a treatment option after bilateral adrenalectomy or complete loss of adrenal function $[1,2]$. Thus, adrenal transplantation in animals may provide valuable information before the clinical use of adrenal transplants. It was reported that adrenal autotransplantation in animals is an appropriate model to study adrenocortical regeneration [3-6], as well as adrenocortical zonation [7-13]. This approach using adrenalectomized and autotransplanted animals, also helps to explore the metabolic effects of corticosterone and other hormones, such as glucagon
\end{abstract}

Received: November 7, 2003

Accepted: February 23, 2004

Correspondence to: Dr. Gonzalo ALLENDE, Departamento de Fisiología y Farmacología, Centro de Ciencias Básicas, Universidad Autónoma de Aguascalientes, Av. Universidad 940, Aguascalientes, Ags, 20100 México and insulin, which are involved in the regulation of carbohydrates, lipids and proteins.

It is well known that hypoglycemia is a common symptom in animals after bilateral adrenalectomy due to the absence of glucocorticoids. It was also demonstrated that hypoglycemia is a potent activator of the hypothalamus-pituitary-adrenal (HPA) axis [14]. Activation of the HPA axis results in increased secretion of corticotrophin-releasing hormone $(\mathrm{CRH})$, which secreted into the hypophyseal-portal vessels and transported to the anterior pituitary, stimulates the synthesis and cleavage of proopiomelanocortin (POMC) into a number of peptides, including adrenocorticotrophic hormone (ACTH) [15]. ACTH released from pituitary corticotrophs, acts on the adrenal cortex to stimulate the secretion of corticosterone in the rat. The stress response is terminated via the negative feedback effect of glucocorticoids by occupying the corticosteroid 
receptors and suppressing the release of ACTH [16].

In a previous study, we reported that in rats with adrenal autotransplants in the spleen 21 days after surgery, plasma corticosterone levels partially (50\%) recover. However, aldosterone levels remain very low [17]. The aim of the present work was to determine plasma concentrations of ACTH, corticosterone, aldosterone, glucagon and insulin, in adrenalectomized rats and adrenalectomized rats with intrasplenic adrenal autografts, and compare the results with those of the controls.

\section{Materials and Methods}

Twelve to fourteen weeks old male Wistar rats weighing 230-290 g were obtained from the colony of the University of Aguascalientes and divided into the following three groups ( $\mathrm{n}=7-10)$ : (1) Sham operated, (2) Adrenalectomized (ADX), and (3) Adrenalectomized with autotransplant of adrenal gland in the spleen $(\mathrm{ADX}+\mathrm{SP})$. Autotransplantation involved bilateral adrenalectomy performed through a dorsal incision under anesthesia with sodium pentobarbital $(30 \mathrm{mg} / \mathrm{kg}$ ip); the adrenals were placed in a $0.9 \%$ $\mathrm{NaCl}$ sterile solution. The right gland was discarded. The left gland was cleaned of all surrounding fat and connective tissue, and inserted into the spleen parenchyma according to the technique described by Allende et al. [17]. All animals were fed with standard Purina chow. The adrenalectomized rats were given $0.9 \%$ $\mathrm{NaCl}$ drinking solution during the entire experimental period (21 days) before sacrifice. In the first week after surgery, the animals with the splenic adrenal transplants received a drinking solution of $0.9 \% \mathrm{NaCl}$. In the second week, the $\mathrm{NaCl}$ concentration was reduced to $0.5 \%$ and, in the third week, they were maintained with tap water. The sham-operated rats, used as control group, were supplied with tap water until the sacrifice. The rats were housed under normal laboratory conditions with regular diurnal light/dark alterations (12 h light/12 h darkness cycles). Three weeks after surgery, rats were sacrificed by decapitation under light ether anesthesia and trunk blood was collected for biochemical measurements. Rats were weighed before sacrifice to determine the average weight in each group. Animals were handled gently by the same operator to minimize stress. The plasma was separated by centrifugation and stored at $-20^{\circ} \mathrm{C}$ until required for assays. The animals were autopsied immediately after the sacrifice to obtain the liver, diaphragmatic muscle (sternal and costal parts), and thymus, which were weighed and then stored at $-20^{\circ} \mathrm{C}$ until total proteins and hepatic glycogen measurements were performed. Spleens with the adrenal graft were fixed in $10 \%$ neutral formaline; then, they were dehydrated, embedded in paraffin, and transversally sectioned at 5-6 $\mu \mathrm{m}$ for histology. Sections were stained with hematoxylin-eosin (H-E) or the MalloryHeidenhain's staining. Total proteins of the various tissues and plasma were determined by the method of Bradford [18]. Hepatic glycogen was measured with the procedure described by Murat and Serfaty [19]. Plasma glucose was determined using the o-toluidine method. Potassium $\left(\mathrm{K}^{+}\right)$and sodium $\left(\mathrm{Na}^{+}\right)$concentrations were measured in a Corning Flame Photometer 410 (UK). Plasma triglycerides and cholesterol were determined using commercial kits purchased from Hycel (Mexico) and Randox (UK), respectively. Plasma corticosterone and aldosterone were determined using Coat-A-Count rat corticosterone and rat aldosterone radioimmunoassay kits; glucagon was measured with a Double Antibody Glucagon radioimmunoassay kit and insulin with a Coat-A-Count insulin radioimmunoassay kit; plasma ACTH was determined using the Immulite ACTH kit for in vitro diagnostic use with the Immulite Analyzer Competitive Immunoassay; all hormone kits were purchased from Diagnostic Products Corporation (Los Angeles, CA, USA). Intra- and interassay variations for ACTH were $10.23 \%$ and $9.21 \%$, respectively; for corticosterone $8.26 \%$ and $6.94 \%$; for aldosterone $8.86 \%$ and $7.19 \%$; for glucagon $5.11 \%$ and $6.22 \%$; and for insulin $8.79 \%$ and $7.48 \%$. All measurements were carried out in triplicate and repeated at least twice. Results are expressed as the mean \pm SEM. The differences between means were compared with an ordinary ANOVA and Tukey multiple comparison test. A $p$ value of less than 0.05 was considered statistically significant. All other commercial reagents used in the experiments were purchased from Sigma Chemical Co. (St Louis, MO, USA).

\section{Results}

\section{Plasma hormone concentrations}

As shown in Table 1, in adrenalectomized rats 
Table 1. Effects of adrenal autotransplantation in the rat spleen on hormonal parameters. The data presented are the means \pm S.E.M. $(n=6-9)$.

\begin{tabular}{lccc}
\hline & (1) SHAM & (2) ADX & (3) ADX+SP \\
\hline Plasma ACTH $(\mathrm{pg} / \mathrm{mL})$ & $53.9 \pm 4.0$ & $897.8 \pm 93.6^{\mathrm{a}}$ & $970.6 \pm 81.5^{\mathrm{a}, \mathrm{b}}$ \\
Plasma corticosterone $(\mathrm{ng} / \mathrm{mL})$ & $141.8 \pm 11.0$ & $11.0 \pm 3.5^{\mathrm{a}}$ & $71.1 \pm 10.6^{\mathrm{a}, \mathrm{c}}$ \\
Plasma aldosterone $(\mathrm{pg} / \mathrm{mL})$ & $99.4 \pm 7.4$ & $6.7 \pm 3.5^{\mathrm{a}}$ & $8.2 \pm 2.5^{\mathrm{a}, \mathrm{b}}$ \\
Plasma glucagon $(\mathrm{pg} / \mathrm{mL})$ & $75.7 \pm 2.5$ & $110.8 \pm 8.2^{\mathrm{a}}$ & $101.0 \pm 3.8^{\mathrm{a}, \mathrm{b}}$ \\
Plasma insulin $(\mu \mathrm{IU} / \mathrm{mL})$ & $2.12 \pm 0.50$ & $0.027 \pm 0.001^{\mathrm{a}}$ & $2.08 \pm 0.32^{\mathrm{c}, \mathrm{d}}$ \\
\hline
\end{tabular}

Statistical comparison of the data: not significant $(p>0.05)$; significantly different $(p<0.05)$; ${ }^{\text {a }}$ significantly different from (1); ${ }^{\mathrm{b}}$ not significant vs (2); ${ }^{\mathrm{c}}$ significantly different from (2); ${ }^{\mathrm{d}}$ not significant vs (1).

Table 2. Effects of adrenal autotransplantation in the rat spleen on biochemical parameters. The data presented are the means \pm S.E.M. $(n=6-9)$.

\begin{tabular}{lccc}
\hline & (1) SHAM & (2) ADX & (3) ADX+SP \\
\hline Plasma glucose $(\mathrm{mg} / \mathrm{dL})$ & $120.8 \pm 3.3$ & $73.8 \pm 1.1^{\mathrm{a}}$ & $114.4 \pm 2.4^{\mathrm{b}, \mathrm{c}}$ \\
Hepatic glycogen $(\mathrm{mg} / 100 \mathrm{mg})$ & $2.30 \pm 0.11$ & $0.78 \pm 0.10^{\mathrm{a}}$ & $1.62 \pm 0.7^{\mathrm{a}, \mathrm{c}}$ \\
Total plasma proteins $(\mathrm{mg} / \mathrm{mL})$ & $71.2 \pm 0.6$ & $51.0 \pm 0.6^{\mathrm{a}}$ & $67.3 \pm 1.2^{\mathrm{b}, \mathrm{c}}$ \\
Total hepatic proteins $(\mathrm{mg} / \mathrm{g})$ & $331.5 \pm 15.6$ & $249.4 \pm 13.1^{\mathrm{a}}$ & $335.9 \pm 8.5^{\mathrm{b}, \mathrm{c}}$ \\
Diaphragma proteins $(\mathrm{mg} / \mathrm{g})$ & $133.1 \pm 4.0$ & $182.6 \pm 4.7^{\mathrm{a}}$ & $136.3 \pm 2.9^{\mathrm{b}, \mathrm{c}}$ \\
Thymus proteins $(\mathrm{mg} / \mathrm{g})$ & $99.4 \pm 3.8$ & $145.2 \pm 3.2^{\mathrm{a}}$ & $110.8 \pm 3.1^{\mathrm{b}, \mathrm{c}}$ \\
Plasma triglycerides $(\mathrm{mg} / \mathrm{dL})$ & $76.1 \pm 11.6$ & $36.8 \pm 4.2^{\mathrm{a}}$ & $38.5 \pm 4.3^{\mathrm{a}, \mathrm{d}}$ \\
Plasma cholesterol $(\mathrm{mg} / \mathrm{dL})$ & $66.1 \pm 3.9$ & $38.6 \pm 2.6^{\mathrm{a}}$ & $65.4 \pm 2.2^{\mathrm{b}, \mathrm{c}}$ \\
Plasma potassium $(\mathrm{mEq} / \mathrm{L})$ & $4.14 \pm 0.16$ & $5.84 \pm 0.47^{\mathrm{a}}$ & $5.93 \pm 0.44^{\mathrm{a}, \mathrm{d}}$ \\
Plasma sodium $(\mathrm{mEq} / \mathrm{L})$ & $172.4 \pm 4.3$ & $138.9 \pm 2.1^{\mathrm{a}}$ & $140.5 \pm 5.6^{\mathrm{a}, \mathrm{d}}$ \\
\hline
\end{tabular}

Statistical comparison of the data: not significant ( $p>0.05)$; significantly different $(p<0.05)$; ${ }^{\text {a }}$ significantly different from (1); ${ }^{\mathrm{b}}$ not significant vs (1); ${ }^{\mathrm{c}}$ significantly different from (2); ${ }^{\mathrm{d}}$ not significant vs (2).

Table 3. Body weights (BW) and liver, diaphragma and thymus weights in sham-operated, ADX and ADX + SP rats, 21 days after surgery (before sacrifice). Results are means \pm S.E.M. $(\mathrm{n}=8-10)$.

\begin{tabular}{lccr}
\hline & (1) SHAM & (2) ADX & (3) ADX+SP \\
\hline Body weight $(\mathrm{g})$ & $294.9 \pm 9.0$ & $274.2 \pm 5.6^{\mathrm{a}}$ & $271.2 \pm 10.3^{\mathrm{a}, \mathrm{b}}$ \\
Liver weight $(\mathrm{g} / 100 \mathrm{~g} \mathrm{BW})$ & $3.4 \pm 0.2$ & $3.2 \pm 0.1^{\mathrm{a}}$ & $3.2 \pm 0.2^{\mathrm{a}, \mathrm{b}}$ \\
Diaphragma weight $(\mathrm{mg} / 100 \mathrm{~g} \mathrm{BW})$ & $183.7 \pm 10.1$ & $185.1 \pm 6.2^{\mathrm{a}}$ & $186.7 \pm 9.7^{\mathrm{a}, \mathrm{b}}$ \\
Thymus weight $(\mathrm{mg} / 100 \mathrm{~g} \mathrm{BW})$ & $55.1 \pm 3.5$ & $72.4 \pm 5.2^{\mathrm{c}}$ & $62.8 \pm 5.8^{\mathrm{a}, \mathrm{b}}$ \\
\hline
\end{tabular}

Statistical comparison of the data: not significant $(p>0.05)$; significantly different $(p<0.05) ;{ }^{\text {a }}$ not significant

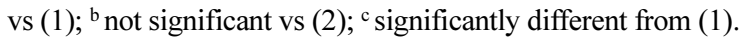

$(\mathrm{ADX})$ and in adrenalectomized rats with intrasplenic adrenal autotransplants (ADX $+\mathrm{SP})$, plasma ACTH levels were approximately 17 and 18 -fold higher, respectively, than in sham-operated control animals (SHAM). In comparison with the SHAM group, in ADX animals plasma corticosterone concentrations were markedly decreased, whereas in ADX + SP rats, corticosterone levels reached a $50 \%$ recovery. In contrast, aldosterone concentrations in the $\mathrm{ADX}+\mathrm{SP}$ group were very low, similar to the values found in the ADX rats. The ADX and ADX + SP animals had a significant elevation in plasma glucagon (46 and 33\%, respectively). Plasma insulin concentrations decreased in the ADX group, whereas in the ADX + SP rats they returned to normal values.

\section{Biochemical parameters in plasma and tissues}

As shown in Table 2, the ADX animals displayed a significant decrease of plasma glucose $(61 \%)$, hepatic glycogen $(34 \%)$, total plasma proteins $(72 \%)$, total hepatic proteins $(75 \%)$, plasma triglycerides $(48 \%)$, 
cholesterol (58\%), and plasma sodium (80\%), as compared with the sham group. The decrease in these parameters coincided with the marked reduction of plasma corticosterone $(8 \%)$ and aldosterone $(7 \%)$ concentrations. The ADX animals also showed a marked increase in total proteins of diaphragma $(37 \%)$ and thymus $(46 \%)$, as well as in plasma potassium $(41 \%)$. In the ADX + SP rats plasma glucose $(95 \%)$, hepatic glycogen $(70 \%)$, plasma $(94 \%)$ and total hepatic (101\%) proteins, and cholesterol (99\%), reached values close to those of the SHAM group. Furthermore, diaphragma (102\%) and thymus (111\%) protein levels in ADX + SP animals, were lower approaching normal values. It should be mentioned, however, that in the ADX + SP rats, plasma potassium levels increased $43 \%$ and plasma sodium levels decreased $19 \%$ compared with the SHAM group. In addition, no recovery of plasma triglycerides was observed $(50 \%)$ in the $\mathrm{ADX}+\mathrm{SP}$ animals. As shown in Table 3, no statistically significant differences were found among the body, liver, diaphragma and thymus average weights of each group, except for the thymus weight of adrenalectomized rats, which was higher and significantly different from the weight measured in the SHAM group. This result can be reasonably explained by the absence of corticosterone secretion in the ADX animals, since the marked glucocorticoids effect on the mobilization of proteins from lymphoid tissues is widely known.

Fig. 1. Light micrographs showing adrenal tissue autografted in the spleen: (a) Thick adrenal capsule (arrow), atrophied adrenocortical cells (large asterisk) and remnants of medullary cells (small asterisk) constitute the bulk of the gland. Magnification: $\times 40$. Bar $=60 \mu \mathrm{m}$. Stain: Mallory-Heidenhain. (b) Non capsular area of the same graft where the spleen and adrenal graft were in contact. Erythrocytes accumulate and splenic sinusoid-like vessels invade the graft. Lymphocytes, macrophages containing brown pigment, fibroblasts, collagen fibers and cellular debris could also be recognized. Magnification: $\times 200$. Bar $=10 \mu \mathrm{m}$. Stain: Mallory-Heidenhain. (c) Nodule of regenerating adrenocortical cells, some in mitoses (arrows) resembling fasciculata-like adrenocortical cells. The nodule is separated from the splenic parenchyma (small asterisk) by a thick connective tissue capsule (star). Magnification: $\times 200$. Bar $=10 \mu \mathrm{m}$. Stain: hematoxylin-eosin.

\section{Morphologic results}

By light microscopy, the adrenal capsule was thicker containing numerous fibroblasts and collagen fibers. In the grafts contrasting changes were apparent; the bulk of adrenocortical tissue was atrophic with coalescent multinucleated cells possessing scarce amorphous
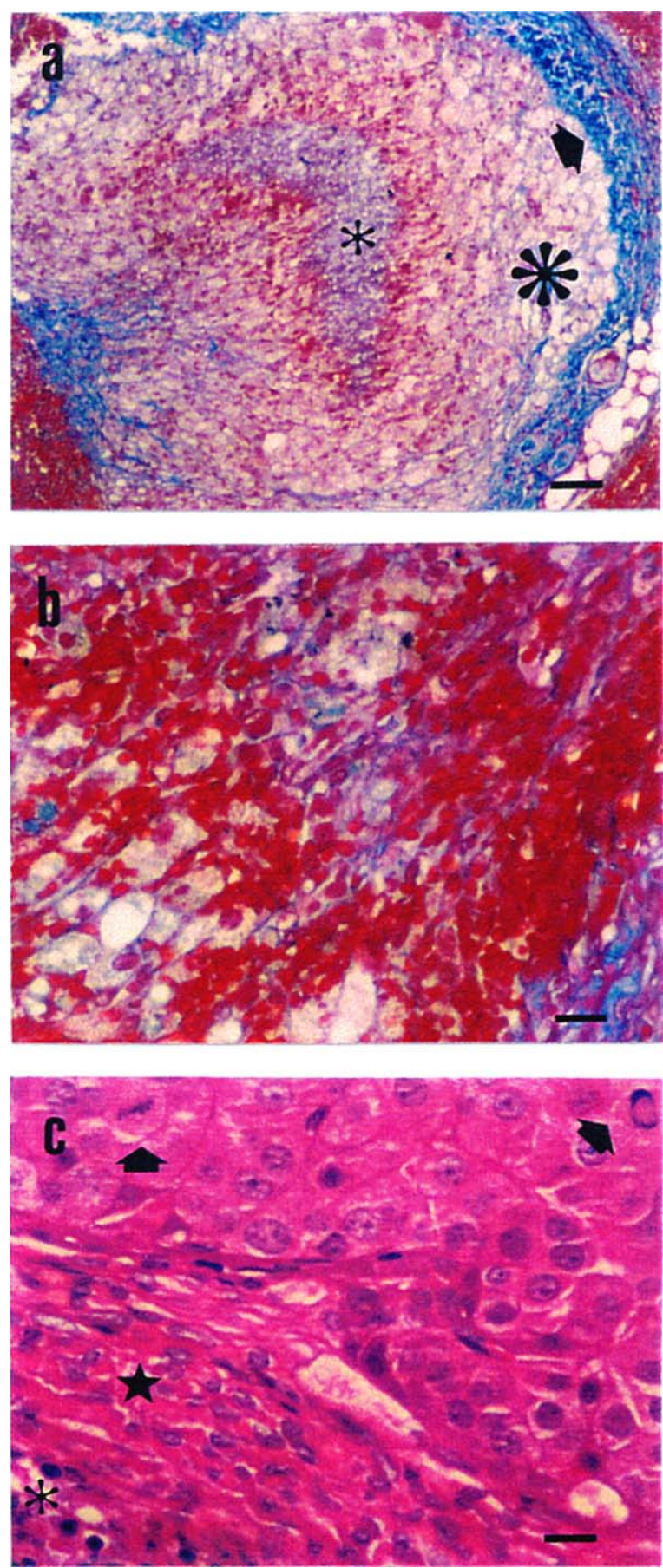
cytoplasm and small irregular nuclei. Medullary cell remnants were also present, consisting of non nucleated cells with empty vacuoles and amorphous cytoplasm (Fig. 1a). In areas where the grafts were in direct contact with the splenic parenchyma, splenic sinusoid-like vessels invaded the graft. Erythrocytes, lymphocytes, macrophages containing brown pigment, fibroblasts, collagen fibers and cellular debris could be noted (Fig. 1b). In the inner border of the capsule, ovoid or spherical well vascularized nodules of several sizes were apparent; they were composed of fasciculata-like cells resembling the cells of the zona fasciculata in the normal adrenal cortex. The cells were arranged in groups or columns. Several mitoses were also observed (Fig. 1c).

\section{Discussion}

Transplantation of adrenal cortical tissue may represent an alternative approach in the treatment of adrenal insufficiency [1,2]. Thus, this procedure in laboratory animals could provide useful information before clinical application of adrenal transplantation. In the present study, working with adrenalectomized rats and adrenalectomized rats with a complete autotransplanted adrenal into the spleen, we measured plasma levels of $\mathrm{ACTH}$, corticosterone, aldosterone, glucagon and insulin, as well as several biochemical parameters related to those hormones, 21 days after surgery.

Our results showed that in adrenalectomized and in autotransplanted animals, as compared with the control sham group, plasma ACTH levels were significantly increased (17 and 18-fold, respectively) (Table 1). These findings were consistent with those reported by other authors in adrenalectomized rats and autotransplanted rats after bilateral adrenalectomy [4, 20, 21]. However, Belloni et al. [4] reported only a $46 \%$ increase of plasma ACTH concentration in autotransplanted animals, a much smaller increase as compared with our data. The reason for this difference could be the longer period between surgery and sacrifice (4 months) compared with the 3 weeks used in our study, which would not allow stabilization of ACTH levels. The high plasma ACTH levels found in adrenalectomized and autotransplanted rats can be explained by the enhanced ACTH release due to the reduction of plasma corticosterone. Moreover, the decreased plasma glucose levels (Table 2) in adrena- lectomized and autotransplanted animals (at least during the first days after transplantation), may also contribute to the increase of plasma ACTH levels, since hypoglycemia is known to be a potent activator of the HPA axis [14].

Plasma corticosterone levels in adrenalectomized animals were very low (Fig. 2a), whereas intrasplenic adrenal autografted animals showed a $50 \%$ recovery (Fig. 2a). This latter result is in agreement with that reported by Vendeira et al. [22]. Belloni et al. [4, 7]
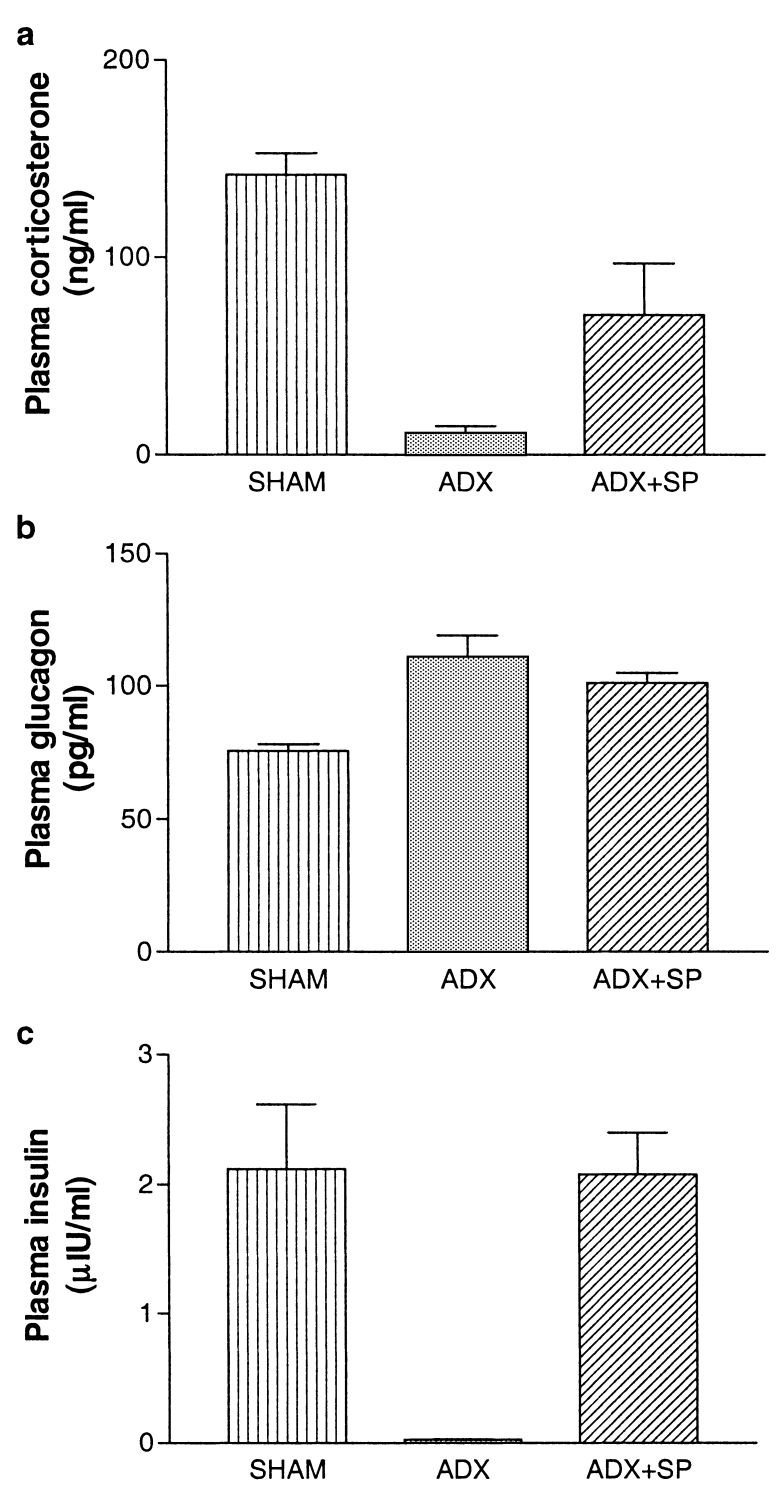

Fig. 2. Effects of adrenal autotransplantation in the rat spleen on: (a) plasma corticosterone (ng/mL plasma), (b) plasma glucagon (pg/mL plasma) and (c) plasma insulin ( $\mu \mathrm{IU} / \mathrm{mL}$ plasma). Each bar represents the mean \pm S.E.M. of values from 6 to 9 animals and the statistical comparisons between groups are shown in Table1. 
noted an almost complete restoration of blood corticosterone levels 4 months after transplantation. The difference between their and our results could be explained by the shorter period between transplantation and sacrifice (21 days) in our experiments, which would allow only a partial regeneration of the transplanted tissue. In spite of this difference, the partial recovery of plasma corticosterone concentrations obtained in our study, was enough to restore the biochemical parameters regulated by this hormone (plasma glucose, hepatic glycogen and plasma, hepatic, muscle and thymus proteins).

In contrast, no recovery of aldosterone plasma levels was evident in autotransplanted animals; these rats showed similar values to those of the adrenalectomized animals (Table 1). These results are in accordance with those of previous studies $[4,7,22]$. The scant aldosterone secretion by the transplanted adrenal accounts for the failure to recover potassium and sodium plasma concentrations in the autografted rats (Table 2). Our histologic findings are also consistent with those reported in previous studies [4, 7, 17, 23]. Most of the parenchymal cells in the regenerating adrenal transplant, closely resembled those of the zona fasciculata in the normal adrenal, and it is well known that these cells are mainly involved in corticosterone secretion. Conversely, very few glomerulosa cells could be seen in the regenerating adrenal, which could account for the scarce plasma aldosterone levels measured in the transplanted animals (Table 1).

We revealed a marked increase of plasma glucagon levels in both adrenalectomized and autotransplanted animals (Fig. 2b), consistent with the assumption that low corticosterone levels detected in those groups, promote increased glucagon secretion by pancreatic $\alpha$-cells, as an homeostatic response to normalize plasma glucose concentration. High glucagon concentrations may also contribute to the marked increase in plasma ACTH levels found in adrenalectomized and autotransplanted rats (Table 1), since previous studies demonstrated that administration of glucagon evokes a considerably rise in the blood levels of ACTH [24, 25]. It has also been reported that systemic or intracerebroventricular administration of glucagon raises plasma concentration of corticosterone in rats [26] and cortisol in humans $[27,28]$. Thus, it may well be that increased glucagon levels contribute to the partial recovery of plasma corticosterone observed in autotransplanted animals (Fig. 2a). Glucagon may act di- rectly on the regenerating adrenal transplant promoting the secretory activity of adrenocortical cells. It should be mentioned in this regard, that glucagon-receptor mRNA was shown to be expressed in the rat adrenal gland $[29,30]$. However, high plasma glucagon concentrations alone were not sufficient to reestablish glucose levels in adrenalectomized rats (Table 2), suggesting that corticosterone is required for gluconeogenic effects of glucagon. Supporting this idea, Friedmann et al. [31] and subsequently Exton et al. $[32,33]$ proposed that glucocorticoids play a permissive role in the hormonal regulation of gluconeogenesis. These authors compared gluconeogenesis in perfused livers of control and adrenalectomized rats, and noted that livers of adrenalectomized animals, which were less responsive to glucagon, became fully responsive 60 minutes after dexamethasone administration. Moreover, Eigler et al. [34] reported that a physiologically relevant increase in normal serum cortisol levels, which alone does not alter glucose production, can potentiate the effects of glucagon in the normal dog.

Plasma triglycerides did not recover in adrenal autotransplanted animals (Table 2). This result can be explained by the increased plasma glucagon levels found in this experimental group (Fig. 2b), since it is well known that glucagon stimulates lipolysis through the activation of hormone-sensitive lipase, which converts triglycerides to free fatty acids and diacyl glycerol.

We found very low levels of plasma insulin in adrenalectomized rats (Fig. 2c), consistent with their hypoglycemic state (Table 2) and the hypocorticosteronemia (Fig. 2a). On the other hand, autotransplanted animals showed an almost complete restoration of plasma insulin levels (Fig. 2c), coinciding with the recovery of plasma glucose and corticosterone levels in this group. Corticosterone could also facilitate insulin recovery. In fact, Malaisse et al. [35] reported a markedly increased insulin release by pancreatic tissue isolated from normal rats treated with cortisol. Cryer and Gerich [36] mentioned that decreased insulin secretion along with increased glucagon secretion, are important in the regulation of glucose metabolism and the recovery from hypoglycemia. Such condition is evident in adrenalectomized rats (Figs. $2 \mathrm{~b}$ and $2 \mathrm{c}$ ), without restoration of plasma glucose (Table 2) and minimal corticosterone levels (Fig. 2a). On the other hand, adrenal autografted animals with a 50\% recovery of plasma corticosterone concentrations (Fig. 2a), 
showed normal plasma glucose (Table 2) and insulin levels (Fig. 2c), as well as high plasma glucagon concentrations (Fig. 2b).

In conclusion, the marked elevation of plasma ACTH in adrenalectomized and autotransplanted rats, can only partially be explained by the lack of negative feedback effect due to low corticosterone levels and by the decreased glucose concentrations. Another factor may be the high glucagon secretion detected in both groups. The increased plasma glucagon levels found in adrenalectomized and autotransplanted animals, suggest that glucagon is important in the restoration of plasma glucose and hepatic glycogen in the autografted animals. Glucagon is not acting alone, but together with the gradually increasing plasma corticos- terone. Thus, it is conceivable that corticosterone plays a major role in the metabolic recovery in autotransplanted animals, allowing the return of most of the biochemical parameters and insulin to normal values.

\section{Acknowledgements}

The authors thank Adriana Rodríguez, Alejandro Organista and Manuel Tinajero for their technical assistance. They are also grateful to Dr. Kalman Kovacs for his continuous support. This study was supported by PIFF 02-2 project from the Universidad Autónoma de Aguascalientes.

\section{References}

1. Ricordi C, Santiago J, Lacy P (1987) Use of culture and temporary immunosuppression to prolong adrenal cortical allograft survival. Endocrinology 121: 745748.

2. Erdogan G, Kologlu S, Kamel N, Baskal N, Cesur V, Eraslan S (1994) Adrenal autotransplantation after total adrenalectomy: delayed determined function. Endocr $J$ 41: 45-48.

3. Belloni A, Vassanelli P, Robba C, Rebuffat P, Mazzocchi G, Nussdorfer G (1982) Ultrastructural observations on the regeneration of adrenocortical autotransplants in the rat spleen. J Anat 135: 245-253.

4. Belloni A, Neri G, Musajo F, Andreis P, Boscaro M, D’Agostino D, Rebuffat P, Boshier D, Gottardo G, Mazzocchi G, Nussdorfer G (1990) Investigations on the morphology and function of adrenocortical tissue regenerated from gland capsular fragments autotransplanted in the musculus gracilis of the rat. Endocrinology 126: 3251-3262.

5. Matsumoto T (1990) Autotransplantation of adrenal cortex into the spleen of dogs. Jpn J Surg 20: 307-315.

6. Nabishah B, Khalid B, Morat P, Zanariyah A (1998) Regeneration of adrenal cortical tissue after adrenal autotransplantation. Exp Clin Endocrinol Diabetes 106: 419-424.

7. Belloni A, Neri G, Andreis P, Musajo F, Boscaro M, Mazzocchi G, Nussdorfer G (1991) Effects of prolonged sodium restriction on the morphology and function of rat adrenocortical autotransplants. Cell Tissue Res 265: 35-41.

8. Rebuffat P, Neri G, Andreis P, Belloni A, Mazzocchi G, Musajo F, Nussdorfer G (1991) Effects of prolonged treatment with adrenocorticotropin on the morphology and function of rat adrenocortical auto- transplants. Cytobios 65: 101-113.

9. Ho MM, Vinson GP (1993) 11ß-Hydroxylase gene expression in the rat adrenal cortex. J Endocrinol 139: 301-306.

10. Ho MM, Barker S, Vinson GP (1994) Distribution of the adrenocortical inner zone antigen. $J$ Endocrinol 141: 459-466.

11. Vendeira P, Pignatelli D, Neves D, Magalhaes MM, Magalhaes MC, Ho MM, Vinson GP (1996) New insights into zonal differentiation of adrenal autotransplants in the rat: an immunohistochemical study. $J$ Endocrinol 149: 497-502.

12. Vinson GP, Ho MM, Puddefoot J (1998) Adrenocortical zonation and the adrenal renin-angiotensin system. Endocr Res 24: 677-686.

13. Teebken O, Scheumann G (2000) Differentiated corticosteroid production and regeneration after selective transplantation of cultured and noncultured adrenocortical cells in the adrenalectomized rat. Transplantation 70: 836-843.

14. Daniels RA, Espiner EA (1975) The plasma cortisol and corticotrope response to hypoglycemia following adrenal steroid and ACTH administration. J Clin Endocrinol Metab 41: 1-6.

15. Mountjoy KG, Wong J (1997) Obesity, diabetes and functions for proopiomelanocortin-derived peptides. Mol Cell Endocrinol 128: 171-177.

16. Reul JM, De Kloet ER (1985) Two receptor systems for corticosterone in rat brain: microdistribution and differential occupation. Endocrinology 117: 2505-2511.

17. Allende G, Chavira R, Quintanar-Stephano A (2001) Biochemical evidence of the functional recovery and regeneration of adrenal autotransplants in the rat spleen. Endocrine 16: 173-179. 
18. Bradford M (1976) A rapid and sensitive method for the quantitation of microgram quantities of protein utilizing the principle of protein-dye binding. Anal Biochem 72: 248-254.

19. Murat J, Serfaty A (1974) Simple enzymatic determination of polysaccharide (glycogen) content of animal tissues. Clin Chem 20: 1576-1577.

20. Engeland WC (1984) Plasma adrenocorticotropin concentration is elevated in adult rats with neonatal adrenal transplants. Endocrinology 114: 2160-2166.

21. Wilkinson CW, Shinsako J, Dallman MF (1981) Return of pituitary-adrenal function after adrenal enucleation or transplantation: diurnal rhythms and responses to ether. Endocrinology 109: 162-169.

22. Vendeira P, Neves D, Magalhaes MM, Magalhaes MC (1996) Modulation of autotransplanted adrenal gland by endothelin-1: a morphological and biochemical study. Anat Rec 246: 98-106.

23. Vendeira P, Magalhaes MM, Magalhaes MC (1992) Autotransplantation of the adrenal cortex: a morphological and autoradiographic study. Anat Rec 232: 262272.

24. Rao RH (1995) Effect of systemic glucagon administration on ACTH secretion in anaesthetized rats. $J$ Endocrinol 145: 51-58.

25. Rao RH, Spathis GS (1987) Intramuscular glucagon as a provocative stimulus for the assessment of pituitary function: growth hormone and cortisol responses. Metabolism 36: 658-663.

26. Larsen PJ, Tang-Christensen M, Jessop DS (1997) Central administration of glucagon-like peptide-1 activates hypothalamic neuroendocrine neurons in the rat. Endocrinology 138: 4445-4455.

27. Waldhausl W, Haydl H, Nowotny P (1976) ACTH and cortisol responses to glucagon stimulation. J Clin Endocrinol Metab 43: 675-678.

28. Littley MD, Gibson S, White A, Shalet SM (1989)
Comparison of the ACTH and cortisol responses to provocative testing with glucagon and insulin hypoglycaemia in normal subjects. Clin Endocrinol 31: 527-533.

29. Svoboda M, Tastenoy M, Vertongen P, Robberecht P (1994) Relative quantitative analysis of glucagon receptor mRNA in rat tissues. Mol Cell Endocrinol 105: 131-137.

30. Hansen LH, Abrahamsen N, Nishimura E (1995) Glucagon receptor mRNA distribution in rat tissues. Peptides 16: 1163-1166.

31. Friedmann N, Exton JH, Park CR (1967) Interaction of adrenal steroids and glucagon on gluconeogenesis in perfused rat liver. Biochem Biophys Res Commun 29: 113-119.

32. Exton JH, Friedmann N, Wong EH, Brineaux JP, Corbin JD, Park CR (1972) Interaction of glucocorticoids with glucagon and epinephrine in the control of gluconeogenesis. J Biol Chem 247: 3579-3588.

33. Exton JH, Miller TB, Harper SC, Park CR (1976) Carbohydrate metabolism in perfused livers of adrenalectomized and steroid-replaced rats. Am J Physiol 230: 163-170.

34. Eigler N, Sacca L, Sherwin RS (1979) Synergistic interactions of physiologic increments of glucagon, epinephrine, and cortisol in the dog: a model for stressinduced hyperglycemia. J Clin Invest 63: 114-123.

35. Malaisse WJ, Malaisse-Lagae F, McCraw EF, Wright PH (1967) Insulin secretion in vitro by pancreatic tissue from normal, adrenalectomized, and cortisol-treated rats. Proc Soc Exp Biol Med 124: 924-928.

36. Cryer PE, Gerich JE (1997) Hypoglycemia in insulindependent diabetes mellitus: interplay of insulin excess and comprised glucose counterregulation. In: Porte D Jr, Sherwin RS (eds) Ellenberg and Rifkin's Diabetes Mellitus. Appleton \& Lange, Stamford, Connecticut, 745-760. 